\title{
China-Africa Economic Ties: Where Agenda 2063 and Belt and Road Initiative Converged and Diverged?
}

\author{
Umar Muhammad Gummi ${ }^{1,2}$, Yang Rong1, Asiya Mu'azu², Chen Ding1 \\ ${ }^{1}$ School of Economics and Management, Xi'an Shiyou University, Xi'an, China \\ ${ }^{2}$ Department of Economics, Sokoto State University, Sokoto, Nigeria \\ Email: *muhammadgummiu@gmail.com
}

How to cite this paper: Gummi, U. M., Rong, Y., Mu'azu, A., \& Ding, C. (2020). China-Africa Economic Ties: Where Agenda 2063 and Belt and Road Initiative Converged and Diverged? Modern Economy, 11, 1026-1039.

https://doi.org/10.4236/me.2020.115077

Received: April 8, 2020

Accepted: May 12, 2020

Published: May 15, 2020

Copyright $\odot 2020$ by author(s) and Scientific Research Publishing Inc. This work is licensed under the Creative Commons Attribution International License (CC BY 4.0).

http://creativecommons.org/licenses/by/4.0/

\begin{abstract}
In recent years, China-Africa economic cooperation uncovered diverse economic potentials in many African countries. As part of its consolidation plans, the African Union in 2013 unveiled "Agenda 2063: The Africa we want". The same year, China lunched its Belt and Road Initiative (BRI) to promote "Community of Common Destiny for Mankind". In this paper, we identify and highlight some points of convergence and divergence between the two initiatives building upon information from official documents issued by governments and the perception of experts both in the private and public sectors of China and Africa. We argue that countries' diversity, projects' life span, institutional and governance inefficiencies and minimal role of African countries in the BRI are some of the key challenges. However, based on the logical appraisal of the plans and their priorities, we argued that China-Africa economic ties promote mutual benefits in the areas of Industrialization, infrastructure and financial integration. Impliedly, we suggest raising the status of Africa and its role in the BRI towards inclusive and sustainable development of both parties.
\end{abstract}

\section{Keywords}

BRI, Agenda 2063, Infrastructural Development, Industrialization, China-Africa Economic Ties

\section{Introduction}

Economic, social and cultural cooperation among nations has become imperative over the years as no one single country can satisfy its different choices endogenously. Though some countries are far rich and developed than others, all 
of them interact, cooperate and exchange values with one another for the common good of their people. Given the uncertain nature of the global economy, cooperation among nations cannot be overemphasized. As part of their regional cooperation and economic strategy, the African Union (Henceforth AU) in 2013 unveiled its Agenda 2063: The Africa We Want-A Strategic Framework for Inclusive Growth and Sustainable Development and at the heart of the Agenda is infrastructural development in African countries, which is considered timely considering the nature of infrastructure and industrial capacity of African countries (AU, 2015a). "The AU closely cooperates with China, in particular on infrastructure development and industrialization since the signing of a Memorandum of Understanding (MoU) on 'The Promotion of Cooperation in Railway, Road, Regional Aviation Networks and Industrialization fields between China and Africa' between the African Union Commission and China's National Development and Reform Commission (henceforth NDRC) in January 2015" (Demissie et al., 2016: p. 24).

China-Africa relationship has a long-standing history dated back to the foundation of Peoples Republic of China in 1949 through a series of reforms and opening-up policies for economic cooperation, engineering and technical exchanges (Tang, 2014). In 2000, the Forum on China-Africa Cooperation (Henceforth FOCAC) was established to mark an unprecedented level of diverse engagements between China and African countries. This approach is to build new and extend the existing bilateral relationships, set up a comprehensive mechanism to better communicate and cooperate. Between 2000 and 2016, FOCAC has organized six ministerial conferences and two summits, namely the Beijing Summit 2006 and Johannesburg Summit 2015. FOCAC greatly facilitated equal consultation, enhanced understanding between high-level officials, expanded consensus and promoted cooperation between China and Africa" (Dimissie et al., 2016: p. 9). In 2013, China announced its "One Belt, One Road" plan to unify and coordinate many of the development initiatives and massive overseas infrastructure projects that China had been funding for the last 10 years. The One Belt, One Road (OBOR) or Belt and Road Initiative (Henceforth BRI) is, in many ways, an extension of the kinds of infrastructure loans already extended to Africa, Asia, and South America. However, while most African countries are FOCAC members, only a few are part of the Initiative. It is a well-known fact that most if not all African countries are hobbling with decayed infrastructure, low level of industrial capacity despite their abundance of natural and human resources. To reverse this trend and open a new historical phase of economic transition, African countries need to be given more attention and an active role in the BRI to complement their sustainability objectives as enshrined in the Agenda 2063 (FOCAC, 2016). Among the key elements of the BRI is infrastructural development and industrialization because of the comparative advantages China has in heavy construction and engineering, sometimes referred to as "construction monsters" (AU, 2015b). 
However, the Belt and Road Initiative has its vision and action plan, dedicated political fora, financial institutions and resources guided by policy road map but the arguments put forth by the paper is that a closer and logical appraisal of the two action plans depicts some convergence points (trade, finance, infrastructure, and sustainability) that will extensively promote the common good of both parties if the status of Africa in the BRI gain more attention and African countries that passed membership criteria are integrated in the initiative.

To this end, the paper seeks to pinpoint and explain the imperatives of China-Africa economic relations, and highlight the points of convergence and divergence of BRI and Agenda 2063 in the light of the initiatives' vision of common good. Through its emphasis on AU's Agenda 2063, the paper provides new insights on China-Africa economic ties through setting policy priorities (infrastructure, industrialization and financial integration) in BRI vision. It further informed and guide policymakers in participating African countries on potential challenges facing BRI in Africa and the need to overcome those challenges toward a new phase for Africa's sustainable development. Accordingly, the paper schemes in eight sections, section two dealt with the prospects of China-Africa economic ties based on experts perception; section three pinpoints the aims and scope of BRI; section four focuses on the priorities of Agenda 2063; in section five, the paper identified main points of convergence between BRI and Agenda 2063; section six highlights the points of divergence (challenges) of BRI in Africa; section seven pinpoints the role of Think Tanks in promoting China-Africa relation; section eight concludes on the implications of the China-Africa economic cooperation in the light of BRI and Agenda 2063.

\section{China-Africa Economic Ties: The Basic Imperatives and Experts' Views}

Although China-Africa relations have a long history, it is only in early 2015 Africa is beginning to become a focus of the BRI Initiative. "On 20 January 2015, Justin Lin Yifu, a leading Chinese economist and former Vice-President of the World Bank, argued that "China should also include Africa in the initiative", expanding it to "One Belt, One Road, One Continent" and that the Initiative's "core task in Africa should be industrial relocation and infrastructure construction" (China Daily 2015). He Wenping, one of China's leading China-Africa researchers, stated that BRI and Africa's development strategy "share the same spirit" and that combining the two "will not only create new momentum for China-African economic ties but also present a new approach for Such cooperation". Referring to the agreement between China and the African Union, she concluded that "the process of combining the strategies from the two sides is already on the way" (Global Times 2015). In October 2015 Lin Songtian, Director General of the Department of African Affairs at China's Ministry of Foreign Affairs (MFA), stated that "China-Africa cooperation is blessed with shared needs, advantages and opportunities, which will make the African continent an important foothold for the One Belt and One Road Initiative" (FOCAC, 2015; 2016). 
Furthermore, Since 2013 Chinese state media has published several different Belt and Road maps with varying indications of Africa's participation in the Maritime Silk Road. In Figure 1, the route through the Indian Ocean towards Kenya, passing Somalia, Djibouti, Eritrea, Sudan and Egypt before continuing in the Mediterranean Sea which shows Africa's potentials to fully participate in the BRI especially the Maritime Silk Road. A spatial analysis of Figure 1 shows that Africa has location advantages that could be fully utilized under BRI.

However, Figure 1 further depicts the historic maritime trade route between China and Kenya during the early 15th century (Wekesa, 2015). Egypt and South Africa are the only ones to have signed MoU with China on the Belt and Road Initiative (People's Daily Online 2016 as cited in Demissie et al. 2016). Also, Mozambique appears to have a privileged role in China's considerations on how Africa will be part of the Belt and Road Initiative. During his visit to Mozambique in February, China's Foreign Minister Wang Yi said that "China will view Mozambique as a natural extension of the 21st Century Maritime Silk Road and boost cooperation with Mozambique in marine economy and port-neighboring industrial parks and transfer its advantageous production capacity and mature technologies to Mozambique" (MFA, 2016). A closer look at the above arguments and issues will convince one that Africa can play a greater role in achieving BRI objectives and targets.

\section{A Brief on the Belt and Road Initiative}

The BRI consists of the Silk Road Economic Belt, which is terrestrial. It involves pathways moving from China to Central Asia, South Asia, the Middle East, Africa, and then Europe. Based on a report published by the Africa Centre for Strategic Studies (ACSS) on 22nd March 2019, “BRI is a China’s signature vision

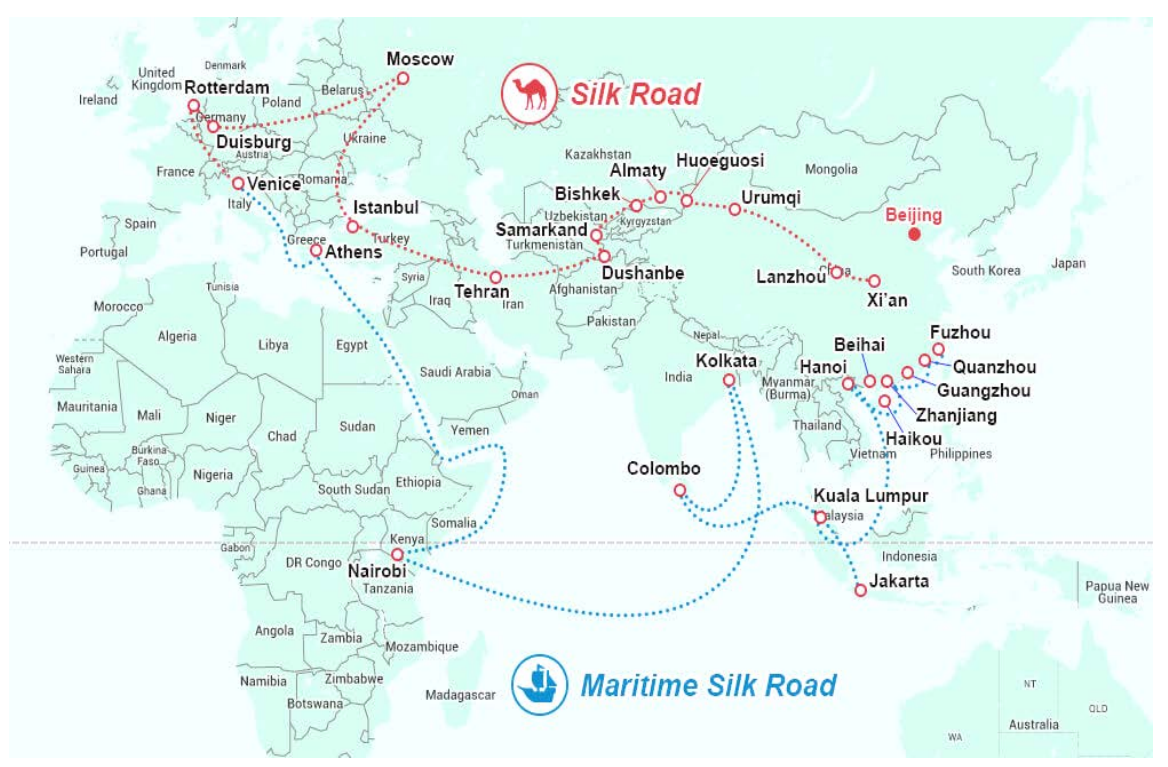

Figure 1. Xinhua map of the silk road economic belt (Silk road) and 21st Century maritime silk road (Maritime silk road). Source: Adopted from Demissie et al. (2016). 
for reshaping its global engagements. It is strategic and comprehensive in scope. It now spans three continents and touches 60 percent of the world's population. The 65 or so countries that have so far signed on the program (including approximately 20 from Africa) account for 30 percent of the worlds' GDP and 75 percent of its energy reserves". The rationale and motive behind BRI are to build a "Community of Common Destiny for Mankind", defined as a new global system of alternative economic, political and security interdependence with China at the center (Paul, 2019). Out of this motive, the initiative set some specific targets that revolve with the framework of the policy action;

- Improve intergovernmental communication and collaboration (policy coordination).

- Build infrastructure (ports, railways, highways, dams, schools, stadiums, bridges, housing) in many different countries (65 to be exact).

- Develop "soft infrastructure" by improving trade agreements, regulatory standards and financial integration.

- Strengthen people-to-people connections through exchanges. The exchanges include students, experts, writers and artists (people-to-people bond).

\section{Agenda 2063: The Priorities}

On adopting Agenda 2063, the AU called on the international community to "respect Africa's vision and aspirations and to align their partnerships appropriately" (AU, 2015). Agenda 2063 and its "First Ten-Year Implementation Plan 2014-2023" together with the African Union's Programme for Infrastructure Development in Africa and Africa's Integrated Maritime Strategy 2050 (AU, 2012 cited in Demissie et al. 2016) on the one hand constitute the basis for Africa's engagement in the BRI and on the other hand should guide China's BRI activities on the continent. The priority areas in the ten-year sub-plan include;

- A high standard of living, quality of life and wellbeing for all citizens.

- Education and skill-driven revolution.

- Transformed economies; sustainable and inclusive economic growth and development, industrialization and value addition, economic diversification and resilience.

- Agricultural productivity and production.

- Marine resources and energy.

- Financial and monetary institutions, fiscal system and public sector revenues.

- Communications and infrastructure connectivity.

- Strong cultural identity, common heritage, values and ethics.

\section{Agenda 2063 and BRI: The Points of Convergence}

In its efforts to foster Africa's development, the AU closely cooperates with China, in particular on infrastructure development and industrialization since the signing of the MoU on "The Promotion of Cooperation in Railway, Road, Regional Aviation Networks and Industrialization fields between China and Afri- 
ca" between the African Union Commission and China's NDRC in January 2015. The MoU followed Premier Li Keqiang's speech at the African Union's headquarters in May 2014 during which he pledged to "actively participate in Africa's industrialization and strengthen industrial cooperation with Africa" as well as "to help Africa achieve the goal of building a high-speed railway network" and "jointly develop regional aviation in Africa" (China Daily Africa, 2014). Based on the motives of the two initiatives, the paper identified some convergence points shared by both initiatives that will go a long way at consolidating the existing China-Africa relations and write a new phase in the history of Africa's development.

\subsection{Infrastructural Development}

In January 2015, the African Union and China signed an agreement to help build railways, roads, and airports to link all 54 African countries. Egypt is of great strategic importance for the Maritime Silk Road as it controls the Suez Canal, which links Asia and Europe. China is supporting numerous infrastructure projects in Egypt, including up to $\$ 15$ billion in financing for the development of the country's $\$ 45$ billion new administrative capital.

Algeria and China agreed to construct a $\$ 3.3$ billion trans-shipment port at Cherchell, $60 \mathrm{~km}$ west of the capital city of Algiers. The port will be constructed by China Harbor Engineering Company (CHEC) and China State Construction Engineering Corporation (CSCEC) (The BRICS Post 2016).

In Djibouti and Ethiopia, the $\$ 4$ billion Djibouti Port-Addis Ababa railway line, which has been mainly financed and built by Chinese partners, is already completed to $97 \%$ and began trial operation in December 2015 (Fana Broadcasting Corporate 2016).

On January 12, 2019, Nigeria's first standard gauge railway, which has been successfully operated for 900 days, had no major accidents since its inception. With the successful completion of the railway construction by China Civil Engineering Construction Company (CCECC), the Abuja Kaduna train service began commercial operation on July 27, 2016. The Abuja-Kaduna Railway Line is one of the first standard railroad railway modernization projects (SGRMP) in Nigeria. This is the first part of the Lagos-Kano standard metrics project, which will connect the business centers of Nigeria with the economic activity centers of the northwestern part of the country.

In May 2014, Premier Li Keqiang signed a cooperation agreement with the Kenyan government to build the Mombasa-Nairobi Standard Gauge Railway connecting Mombasa to Nairobi. The railway cost US\$3.2bn and was Kenya's biggest infrastructure project since its independence. The railway was claimed to cut the journey time from Mombasa to Nairobi from 9 hours by bus or 12 hours on the previous railway to 4.5 hours. In May 2017, Kenyan President Uhuru Kenyatta called the $470 \mathrm{~km}$ railway a new chapter that "would begin to reshape the story of Kenya for the next 100 years". According to Kenya Railways Corpo- 
ration, the railway carried 1.3 million Kenyans with $96.7 \%$ seat occupancy and 600,000 tons of cargo in its first year of operation. Chinese media claim that the railway line boosted the country's GDP by $1.5 \%$ and created 46,000 jobs for locals and trained 1,600 railway professionals (Nairobi Business Monthly, 2016).

The governments of Senegal and Mali have entered into \$2.73 billion agreements with the China Railway Construction Corporation on the repair and reconstruction of the $1286 \mathrm{~km}$ railway between the port of Dakar and Bamako. The agreement includes staff training and the modernization of 22 railway stations (Railway Gazette, 2016).

In Cameroon, China Harbour Engineering Company has constructed the \$1 billion Kribi Industrial Port Complex with $85 \%$ of the costs financed by China EXIM Bank. Cameroon's first deepwater port is being connected to urban areas, including Yaoundé via roads and railway links constructed by Chinese companies (The Diplomat 2015). The transition from infrastructural decay to infrastructural development is becoming a possibility in Africa given the level of cooperation between China and Africa with the intense commitment of resources from both parties towards a new phase of development.

\subsection{Industrialization}

The China-Africa industrial cooperation, demonstration and pioneering countries are Ethiopia, Kenya, Republic of Congo, Tanzania while China-Africa industrial cooperation priority countries are Angola, Egypt and Mozambique. At the FOCAC Johannesburg Summit, 49 Heads of State and Government of African countries and China committed to "actively carry out industry partnering and industrial capacity cooperation, while never pursuing development at the cost of the long-term interests and environments of their host countries" (Mail and Guardian Africa, 2016). They further agreed to "select several African countries to set up pilot and demonstration programs ... for driving forward China-Africa industrial partnering and industrial capacity cooperation in a comprehensive and orderly fashion. Tanzania's largest industrialization project, co-financed by China, is the $\$ 10$ billion construction of the Bagamoyo deep water port and the adjacent EDZ, a trade and logistics center, and a residential area.

Following a state visit by Angola's President Jose Eduardo Dos Santos, China and Angola agreed to "transform the bilateral cooperation from the traditional areas of raw materials development and project contracting to production capacity and investment cooperation" by strengthening cooperation on industrialization in the areas of iron and steel, building materials, textiles and agro-processing (MFA, 2015). Following this agreement, the first loans for the development of industrial zones were made available by China in April 2016 (Macau Hub, 2016).

In January 2016, China and Egypt signed an industrial agreement during Xi Jinping's visit. The two countries entered into strategic cooperation focusing on industrial and infrastructure development. They also signed MoU on jointly implementing the Belt and Road Initiative and agreed to develop Egypt into a pivot of the Belt and Road Initiative (China Daily, 2016). 
Moreover, in a meeting with President Filipe Jacinto Nyusi in May 2016, President Xi Jinping pledged to strengthen cooperation with Mozambique on the industrial capacity to tap the potential of its rich natural and human resources for economic development. Xi also said that he looks forward to closer cooperation with Mozambique within the framework of the 21st Century Maritime Silk Road to boost the maritime economy, fisheries and port development (People's Daily Online 2016).

Ethiopia's Eastern Industrial Zone is a manufacturing hub outside Addis Ababa that was built by China and occupied by factories of Chinese manufacturers. According to Chinese media and the vice director of the industrial zone, there were 83 companies residents within the zone, of which 56 had started production. However, a study in Geoforum noted that the EIZ has yet to catalyze Ethiopia's overall economic development due to many factors including poor infrastructure outside the zone. Discrepancies between the two countries' industries also mean that Ethiopia cannot benefit from direct technological transfer and innovation.

From this view, Africa's industrial capacity and deepening are gaining momentum within China-Africa cooperation could be taken to a greater height if more African countries are integrated into the BRI.

\subsection{Financial Integration and Development}

In 2011, Nigeria, South Africa, Kenya, Ghana, Angola, and Tanzania, claimed to be including Renminbi (RMB) assets into their foreign exchange reserves through different ways, such as shifting reserves from other currencies, investing in China's bond markets, and signing swap agreements between central banks. This is targeted toward hedging exchange rate risk and enhance financial, economic and trade cooperation with China (Demissie et al. 2016). With Chinese-owned banks playing increasingly vital roles in the process, the Belt and Road Initiative is expected to significantly boost the internationalization of the $\mathrm{RMB}$ in Africa. As financial integration is an important underpinning for implementing the Belt and Road Initiative, the Initiative emphasizes on "building a currency stability system, investment, and financing system and credit information system in Asia" and to "expand the scope and scale of bilateral currency swaps and settlement with other countries" (NDRC, 2015). So far, Bank of China (BOC) has launched five offices in Africa, with two branches in South Africa and Zambia, which have been authorized by BOC as RMB clearinghouses, and representative offices in Kenya, Angola, and Morocco. In a nutshell, financial agreements between China and Africa have gain prominence over the years as can be seen in Table 1 .

\section{Points of Divergence: The Challenges of BRI in Africa}

Despite the much anticipated prospects of the BRI in Africa, The size and scope of the initiative are ambitious, posing many challenges: practical, economic and 
Table 1. Financial integration activities between China and Africa.

\begin{tabular}{|c|c|c|}
\hline Year & Entity & Activity \\
\hline 1997 & Bank of China & $\begin{array}{l}\text { Bank of China Zambia Branch was set up as the } \\
\text { first Chinese financial institution in Africa }\end{array}$ \\
\hline 2008 & $\mathrm{ICBC}$ & $\begin{array}{l}\text { Bought a } 20 \% \text { stake in Standard Bank } \\
\text { South Africa for } \$ 5.4 \text { billion. }\end{array}$ \\
\hline 2010 & Bank of China & $\begin{array}{l}\text { Establishment of the Bank of China } \\
\text { Johannesburg Branch. }\end{array}$ \\
\hline 2011 & Central Bank of Nigeria & $\begin{array}{l}\text { Announcement to convert } 5 \%-10 \% \text { of its foreign } \\
\text { exchange reserves from } \$ \text { into RMB }\end{array}$ \\
\hline 2012 & $\begin{array}{c}\text { Central Banks of } \\
\text { Nigeria and Tanzania }\end{array}$ & $\begin{array}{l}\text { Bought 3-year dim sum bonds worth RMB } 500 \\
\text { million, along with other } 3 \text {-year bonds worth } \\
\text { RMB } 1.5 \text { billion and } 20 \text {-year bonds worth } \\
\text { RMB } 1 \text { billion. }\end{array}$ \\
\hline 2013 & $\begin{array}{c}\text { Central Banks of } \\
\text { South Africa and China }\end{array}$ & $\begin{array}{l}\text { The agreement that enabled Standard Bank } \\
\text { South Africa to invest about USD } 1.5 \text { billion } \\
\text { in China's inter-bank bond market. }\end{array}$ \\
\hline 2014 & $\begin{array}{l}\text { China and the } \\
\text { Republic of Congo }\end{array}$ & $\begin{array}{l}\text { The governments of China and the Republic } \\
\text { of Congo establish the Sino-Congolese Ban } \\
\text { for Africa as a joint venture. }\end{array}$ \\
\hline 2015 & $\mathrm{ICBC}$ & $\begin{array}{l}\text { Bought another } 60 \% \text { stake in Standard } \\
\text { Bank South Africa. }\end{array}$ \\
\hline 2015 & $\begin{array}{l}\text { Central banks of } \\
\text { South Africa and China }\end{array}$ & $\begin{array}{l}\text { Signature of a 3-year bilateral swap agreement } \\
\text { for the exchange of local currencies of up to } \\
\text { RMB } 30 \text { billion. }\end{array}$ \\
\hline 2015 & People's Bank of China & $\begin{array}{l}\text { Bank of China Johannesburg Branch appointed as } \\
\text { the first RMB clearing house in Africa. }\end{array}$ \\
\hline 2015 & China Commercial Bank & $\begin{array}{l}\text { Launch of trail operations in Tanzania as the } \\
\text { first Chinese owned private bank in Africa. }\end{array}$ \\
\hline 2015 & People's Bank of China & $\begin{array}{l}\text { Bank of China Zambia Branch appointed as } \\
\text { a second RMB clearing house in Africa }\end{array}$ \\
\hline 2015 & $\begin{array}{c}\text { ICBC and South African } \\
\text { Reserve Bank }\end{array}$ & $\begin{array}{l}\text { Signature of a bond corporation agreement which } \\
\text { entrusted ICBC to issue bonds worth } 10 \text { billion } \\
\text { ZAR, to finance the process of industrialization } \\
\text { and infrastructure construction in South Africa. }\end{array}$ \\
\hline 2015 & Central Bank of Zimbabwe & $\begin{array}{l}\text { Announcement to approve RMB as legal currency } \\
\text { for public domestic transactions. }\end{array}$ \\
\hline 2016 & Bank of China & $\begin{array}{l}\text { Acquisition of banking license from the } \\
\text { Central Bank of Mauritius for setting up the } \\
\text { Bank of China Mauritius Branch. }\end{array}$ \\
\hline $\begin{array}{c}\text { By late } \\
\text { March } 2016\end{array}$ & ICBC & $\begin{array}{l}\text { ICBC had loaned about } \$ 15.6 \text { billion to } 58 \\
\text { China-Africa cooperation programs in over } \\
20 \text { African countries. }\end{array}$ \\
\hline 2016 & $\begin{array}{c}\text { Central Banks of } \\
\text { China and Morocco }\end{array}$ & $\begin{array}{l}\text { The signing of a } 3 \text {-year bilateral swap agreement } \\
\text { for the exchange of local currencies of up to } \\
\text { RMB } 10 \text { billion. }\end{array}$ \\
\hline
\end{tabular}




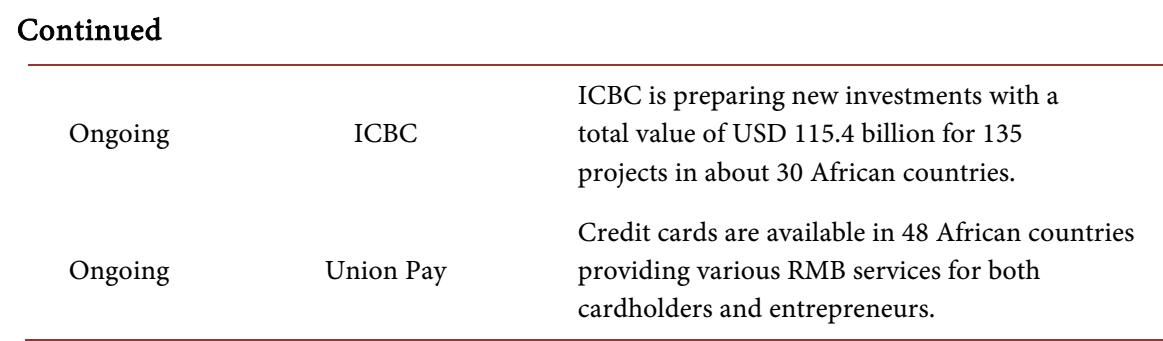

Adopted from Demissie et al. (2016).

political. The BRI vision document leaves much room for speculation and contemplation as to what extent and how African countries will be part of the Initiative. One of the obvious difficulties of evaluating the OBOR initiative is the implicit assumption that it will succeed, or at least, be largely successful. In reality, such a plan faces massive challenges which could slow, even derail, its adoption, or limit the anticipated economic benefits (Enderwick, 2018). In this section, we briefly consider the points of divergence that may poses threat to the success of the BRI in Africa. Overall, major challenge results from the considerable diversity of the constituent countries to the initiative. They vary in terms of income levels with 9 low-income countries, 16 low- to middle-income countries, 14 upper middle-income economies, and 7 high-income countries. They also display enormous variation in terms of infrastructure potential as measured by land mass, population, road, and rail density (Enderwick, 2018). Many of these countries especially in Africa suffer major infrastructure deficiencies and their trade links with China also vary markedly with much lower trade rates with South, Central, and Western Asia. Industry variation is also one of the significant challenges a model to overcome these difference is yet to be in motion. Obstacles to doing business also vary across the region with problems arising from administrative delays and poor quality infrastructure (World Economic Forum, 2016). Policy coordination is also likely to be adversely affected by differences in policy approaches and institutional quality between BRI participants in Africa. A number of participant countries are prone to economic and political instability and widespread corruption. In addition, the financing model of private public partnerships will also be affected by the credit worthiness and sovereign risks found in member countries. Several countries, such as Kenya, Egypt and Syria, carry high levels of political risk, while others such as Ethiopia and Mozambique; carry high default risk ratings (Villafuerte et al., 2016; Bennis, 2016).

The initiative stems from the considerable time span and this may realistically be 35 to 50 years. So, assessment of trade and growth impacts over such a time period is fraught with uncertainties. Nevertheless, the impact of the BRI initiative will depend on the effective management of the proposed projects. Funding misdirected to wasteful projects renders any assessment based on plausible multiplier effects futile, so that ensuring sound governance is critical. This is particularly true for a funding model based on private-public partnerships that require transparency, effective cross-border regulation, and adherence to something close to market principles (Enderwick, 2018). African countries within the BRI 
vary in terms of effective governance and strong institutions from those such as Egypt with relatively strong governance, to others, for example, Mozambique, where it is much weaker. Another point of divergence is the fact that the monetary value of projects across countries may be misleading when significant productivity or efficiency effects occur. Where the private sector is involved in infrastructure projects, it is likely to reduce the public debt burden, encourage knowledge sharing, and the adoption of best practice. Efficiency is also subject to synergistic integration of the many projects proposed as interdependency is a key characteristic of the BRI. In other words, the routes, and their transaction costs, are only as effective as the weakest link. We might anticipate significant productivity enhancing effects when Chinese contractors take on the majority of the work because of weaknesses within the private sector of many participant economies. Large-scale infrastructure development is an area in which China displays competitive strength. It is also important to acknowledge that while China is displaying a strong external orientation, it is also simultaneously dealing with a number of domestic tensions that could detract it from the BRI (McKinsey, 2016). Critical among these are growing regional disparities, increasing debt levels, the restructuring of heavy industry, and the need to tackle environmental concerns. While the BRI may contribute to tackling some of these issues as enshrined in its vision, they will still require policy focus.

Finally, it is clear that the BRI represents a new phase of China's foreign poli$c y$, one that seeks to have a greater external impact and focused on regions that have not benefitted as much from the current era of globalization as others. However, the focus of the BRI is still on exports, especially of infrastructure construction. This suggests that the initiative will need to be evaluated in more than simply trade terms: but other aspects of human existence are also important and considerable as trade will be accompanied by the exchange of capital (technology), policies, and people (peaceful co-existence).

\section{The Role of Think Tanks}

It is worthy to note at this juncture that the BRI became one of the interesting issues among intellectuals and academicians around the globe. It is hard to find a think tank that is not involved in research in this area. For policy analysis and implementation purposes government-related think tanks, especially those affiliated with ministries, play a particularly important role, for example, in China, NRDC's International Cooperation Center, MOFCOM's Chinese Academy of International Trade and Economic Cooperation (CAITEC) and the Development Research Center of the State Council (DRC). Other important research institutes include the Chinese Academy of Social Sciences (CASS), China Institutes of Contemporary International Relations (CICIR), Shanghai Institutes for International Studies (SIIS), Unirule Institute for Economics, Chongyang Institute for Financial Studies (RDCY), China Institute of International Studies (CIIS) and the Center for China and Globalization (CCG).

Based on their link with key government ministries, these institutions' have 
comparative advantages in obtaining information regarding plans and progress of the Initiative. On the other hand, they are often confined to take a very partisan or positive position, not necessarily asking hard questions or examining challenging issues or data relating to the Initiative. University think tanks have also been contributing research, and tend not to be as constrained as the Government-affiliated institutions. Researches on Africa's role in the Initiative or the impact of the initiative on Africa are not given priority and severely lacking. As we increasingly see indications of the involvement of certain parts of Africa in the Initiative, for example, in East Africa, this situation may change in the future if the Think Tanks could render more attention on the role of Africa and disseminate their reports on areas that need improvement for the common good of all stakeholders.

\section{Conclusion}

China-Africa economic tie is gaining momentum over the years. With the unveiling of BRI by China and Agenda 2063 by the AU as part of their regional cooperation and economic strategy, more prospects and opportunities are expected to be uncovered by the cooperation for the common good of both parties. However, the BRI has its vision and action plan, a dedicated political strategy for financial institutions and resource allocation guided by the policy road map. Impliedly, Africa's diversity, institutional and governance challenges as well as the limited role of African countries in the BRI are clearly the challenges that require urgent action. However, the main argument is that both the initiatives converged at some priorities (infrastructural development, industrialization and financial integration), and these priorities represent the hub of sustainable and inclusive growth strategy. Furthermore, raising the status of Africa and its role in the BRI will complement the new phase of Africa's development initiatives.

\section{Acknowledgements}

We thank Mika'ilu Abubakar and Abdulaziz Shehu for helpful comments. The stimulating discussions and observations from Tukur Garba and Nura Koko are also appreciated by the authors. We are also thankful to colleagues especially from Xi'an Shiyou University and Sokoto State University for their comments and constructive observations on this piece. All remaining errors are our own.

\section{Funding}

The second and fourth authors acknowledged the financial support from the Scientific Research Program Funded by Shaanxi Provincial Education Department (Program No. 19JZ051). The authors also acknowledge the support of Nigeria's Petroleum Technology Development Fund (PTDF).

\section{Conflicts of Interest}

Authors declare no conflicts of interest regarding the publication of this paper. 


\section{References}

African Union AU Commission (2015a). Agenda 2063. The Africa We Want (Final Edition). https://www.un.org/en/africa/osaa/pdf/au/agenda2063.pdf

African Union AU Commission (2015b). Agenda 2063. The Africa We Want. A Shared Strategic Framework for Inclusive Growth and Sustainable Development. First Ten-Year Implementation Plan 2014-2023.

https://www.un.org/en/africa/osaa/pdf/au/agenda2063-first10yearimplementation.pdf

Bennis, S. (2016). The Morocco-China Partnership and Its Impact on Western Sahara. https://www.alaraby.co.uk/english/comment/2016/5/19/the-morocco-china-partnershi p-and-its-impact-on-western-sahara

China Daily (2015). China EximBank Steps Up Financial Support for Belt and Road. http://www.chinadaily.com.cn/china/2016-01/15/content 23109573.htm

China Daily (2016). China, Egypt Zone in Tianjin to Expand. http://www.chinadaily.com.cn/business/2016-06/28/content 25879647.htm?bsh bid=1 $\underline{133044844}$

China Daily Africa (2014). China Boosts Angola's Reconstruction, Economic Takeoff. http://africa.chinadaily.com.cn/africa/2014-05/09/content 17497000.htm

Demissie, A., Wiegel, M., \& Tang, X. (2016). China's Belt and Road Initiative and Its Implication for Africa. WWF Kenya, Nairobi Kenya.

Enderwick, P. (2018). The Economic Growth and Development Effects of China's One Belt One Road Initiative. Strategic Change, 27, 447-454.

https://doi.org/10.1002/jsc.2229

Forum on China-Africa Cooperation FOCAC (2015). The Forum on China-Africa Cooperation Johannesburg Action Plan (2016-2018).

https://www.focac.org/eng/zywx 1/zywj/t1327961.htm

Forum on China-Africa Cooperation FOCAC (2016). Address by Director-General Lin Songtian at the 5th Meeting of China-Africa Think Tanks Forum.

http://ke.china-embassy.org/eng/zfgx/t1356854.htm

Global Times (2015). “One Belt, One Road” Can Find a Place for Africa. http://www.globaltimes.cn/content/904823.shtml

Macau Hub (2016). China's Credit Lines Make It Possible to Build Industrial Hubs in Angola. https://doi.org/10.12968/prma.2016.26.1.26

http://www.macauhub.com.mo/en/2016/04/26/chinas-credit-lines-make-it-possible-tobuild-industrial-hubs-in-angola

Mail and Guardian Africa (2016). African Countries Bid for "Anchor Points" in China's Billion-Dollar Silk Road Plan-It Could Set off "Mini Battles".

http://mgafrica.com/article/2016-05-29-african-countries-bid-to-be-anchor-points-forchinas-billion-dollar-silk-road-initiative

McKinsey (2016). China's One Belt, One Road: Will It Reshape Global Trade? McKinsey Global Institute, July.

MFA Ministry of Foreign Affairs of the People's Republic of China (2015). Li Keqiang Meets with President José Eduardo dos Santos of Angola. http://www.fmprc.gov.cn/mfa eng/zxxx 662805/t1273408.shtml

MFA Ministry of Foreign Affairs of the People's Republic of China (2016). Joint Statement of Coordinators' Meeting of the Implementation of the Follow-Up Actions of the Johannesburg Summit of the Forum on China-Africa Cooperation (FOCAC). http://www.fmprc.gov.cn/mfa eng/wjb 663304/zzjg 663340/fzs 663828/gjlb 663832/3 044 664114/3046 664118/t1338753.shtml 
Nairobi Business Monthly (2016). Special Economic Zones: The Next Big Thing in Kenya. http://www.nairobibusinessmonthly.com/money/special-economic-zones-the-next-big -thing-in-kenya

NDRC National Development and Reform Commission of the People's Republic of China (2015). Vision and Actions on Jointly Building Silk Road Economic Belt and 21st-Century Maritime Silk Road. http://en.drc.gov.cn/2015-10/13/content 22174539.htm

Paul, N. (2019). Implications for Africa from China's One Belt One Road Strategy. Africa Center for Strategic Studies.

https://africacenter.org/spotlight/implications-for-africa-china-one-belt-one-road-strat egy

People's Daily Online (2016). China, Mozambique Establish Comprehensive Strategic Cooperative Partnership. http://en.people.cn/n3/2016/0519/c90883-9060049.html

Railway Gazette (2016). Senegal-Mali Railway Modernization Agreements Signed. http://www.railwaygazette.com/news/infrastructure/single-view/view/senegal-mali-rail way-modernisation-agreements-signed.html

Tang, X. Y. (2014). China-Africa Economic Diplomacy and Its Implication to Global Value Chains. Beijing: World Knowledge Publishers. (In Chinese)

Villafuerte, J., Corong, E., \& Zhuang, J. (2016). The One Road One Belt Initiative: Impact on Trade and Growth. In 19th Annual Conference on Global Economic Analysis. https://www.gtap.agecon.purdue.edu/resources/download/8280.pdf

Wekesa, B. (2015). China's Silk Road Economic Belt: African Perspectives and Implications. African East-Asian Affairs, No. 1 \& 2, 144-161. https://doi.org/10.7552/0-1-2-157 